${ }^{1}$ Licentiate in Medicine.

${ }^{2}$ Psychologist, Doctor in

Educational Sciences.

Universidad de Concepción,

Faculty of Medicine. Concepción,

Chile.

Recibido el 23 de diciembre de 2020, aceptado el 1 de octubre de 2021.

Correspondence author: Cristhian Pérez-Villalobos Chacabuco esquina Janequeo, Departamento de Educación Médica (5to piso), Facultad de Medicina, Universidad de Concepción. cperezv@udec.cl

\section{When it is time to decide: factors associated to the choice of a medical specialty}

\author{
MARION HOHF-NOVA ${ }^{1}$, RICARDO HUN-PACHECO', \\ DIEGO MUÑOZ-BUSTOS ${ }^{1}$, ALONSO SOTO-CARRIEL ${ }^{1}$, \\ CRISTHIAN PÉREZ-VILLALOBOS ${ }^{2}$
}

\begin{abstract}
After finishing their initial education, physicians can enter post-graduate training programs. In Chile, there are multiple medical specialties options. This review synthesizes the factors associated with the choice of specialty, according to international publications. Students coming from rural areas or small towns would tend to choose Family Medicine. Men prefer specialties such as Surgery. Having relatives in the medical profession, specializing in a specific field, also influence the choice. Concerning interests and preferences, these are linked to personal traits and some biological variables. The inclination towards clinical or surgical fields could be predicted. Academically, the curriculum, good learning experiences and teacher models favor choice, while the harassment suffered could contribute to avoidance. Besides, both prestige and economic prospects are influential factors in the choice and specialties such as Surgery are preferred. The choice of specialty must reach a balance between the students' interests and public health needs. Identifying these factors would allow a better understanding of the present shortfall (or surplus) in certain fields and contribute to the definition of policies and decision-making.
\end{abstract}

(Rev Med Chile 2021; 149: 1352-1359)

Key words: Education, Medical, Graduate; Medicine; Students, Medical.

\section{Cuando es tiempo de decidir: factores asociados a la elección de especialidades médicas}

Concluida su formación, los médicos pueden acceder a programas de formación de postgrado; en Chile existen múltiples opciones de especialización médica. Esta revisión narrativa busca sintetizar los diversos factores asociados con la elección de especialidad médica según la literatura internacional. Entre los resultados se observa que los alumnos provenientes de zonas rurales o ciudades pequeñas tenderían a elegir Medicina Familiar. Los hombres tendrían mayor predilección por especialidades como Cirugía. También influiría ser hijos de médicos especialistas en un área específica. En cuanto a los intereses y preferencias, éstas se conjugan con rasgos de personalidad y algunas variables biológicas, que podrían predecir la elección de especialidades hacia el tipo clínico o quirúrgico. En lo académico, el curriculum, una buena experiencia y modelos docentes fa- 
vorecen la elección, mientras el maltrato sufrido podría contribuir al descarte. Además, tanto el prestigio como el potencial económico de ciertas especialidades ha sido un factor influyente en la elección: se prefieren especialidades como Cirugía. La elección de especialidad debería encontrar un equilibrio entre los intereses del estudiante y las necesidades de salud pública. Identificar todos estos factores, permitiría una mejor comprensión de la actual escasez o sobrecarga en determinados campos, y contribuiría en la construcción de políticas y toma de decisiones, con el fin de mejorar el reclutamiento de estudiantes.

Palabras clave: Educación de Postgrado en Medicina; Estudiantes de Medicina; Medicina.

\section{Antecedents and role of specialization}

I $t$ is usual for medical students attending social events, that even before they can get a bite to eat, someone asks: what are you going to specialize in?

Physicians' training is a process that lasts from 6 to 7 years in Chile. A further formation process can take place through a post-graduate program lasting 2 to 5 years, going on in hospitals and accredited health centers, to acquire a fund of specialized medical knowledge. Although this is the expression of an individual growth decision, the formation of specialists affects the country's development ${ }^{1}$. This narrative review aims to identify what factors affect this choice.

In 2014 the Chilean Ministry of Health (MINSAL) showed a shortage of specialists in the public system, hitting about 1,500,000 users. From then on, the number of quotas and formation centers for new specialists has grown, and the number of grants supporting them. This also creates multiple medical specialty options, for physicians' dependent and not dependent from the MINSAL ${ }^{2}$.

Different factors determine the choice of a medical specialty; these have been studied more closely since the nineties. This, because since then physicians choose primary care specialties less frequently (Pediatrics, Family Medicine or Internal Medicine), and this impacts on health systems and patients' care ${ }^{3}$. But even earlier and among the first studies, one carried out in the United States in 1960 addressed the relationship between physician's personality types and specialties, presenting the hypothesis that those traits induce the choice of the specialty to follow ${ }^{4}$. Since then, not only the influence of personality, but also the link with socio-demographic and academic factors, as well as the work prospects of the students have been examined, and there are publications on this subject from various countries, such as Peru, Sweden or Japan.

There are diverse medical specialty options, in Chile the two major systems are: primary specialties and sub-specialties, specified in Table $1^{5}$.

Studies vary as to the timing of the student's assessment, but few survey the timing of the choice. Among the latter, a study carried out in the UK showed that half the students would make a final choice of specialty during their first year at the School of Medicine ${ }^{6}$. This differs from the evidence of a study carried out in Mexico, where the choice occurred during the final years of university formation. On the other hand, surgeons make a specialty choice earlier, even before entering the school of medicine ${ }^{7}$.

The choice of a medical specialty process is influenced by different factors, which are synthesized below in four groups (Figure 1).

\section{Socio-demographic factors}

The students' home location is one of the factors examined, whether they lived and studied in rural or urban areas before entering Medicine and, finding that in diverse countries, students coming from rural areas or smaller cities would opt for Family Medicine with greater frequency ${ }^{8}$. Other studies stated that there are no significant links between the location of origin and the choice of medical specialty ${ }^{9}$.

Gender differences are now studied more frequently due to the present feminization of Medicine; these are perceived in studies from different countries (Japan, Syria, and Mexico) where it was 
Table 1. List of medical specialties programs accredited by the Association of Medical Schools of Chile (ASOFAMECH)

\begin{tabular}{|c|c|}
\hline Primary specialties & Sub-specialties or specialties derived from the Primary \\
\hline Pathological Anatomy & \multirow{2}{*}{$\begin{array}{l}\text { Derived from Anesthesiology: } \\
\text { - Intensive Medicine }\end{array}$} \\
\hline Anesthesiology & \\
\hline General Surgery & \multirow{5}{*}{ 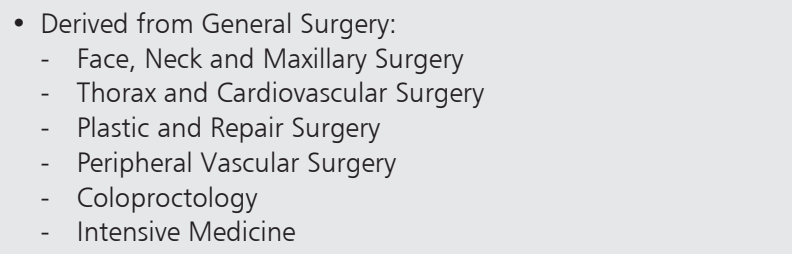 } \\
\hline Pediatric Surgery & \\
\hline Dermatology and Venereology & \\
\hline Clinical Genetics & \\
\hline Clinical Laboratory & \\
\hline Family Medicine & \multirow{10}{*}{ 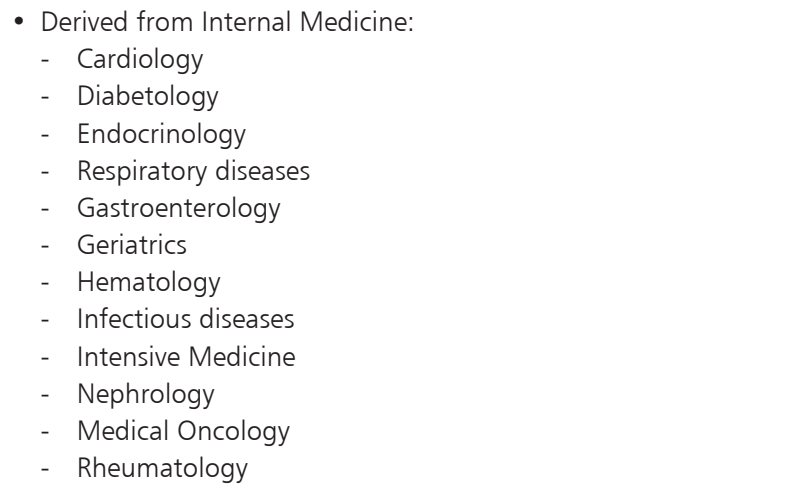 } \\
\hline Physical Medicine \& Rehabilitation & \\
\hline Internal Medicine & \\
\hline Forensic Medicine & \\
\hline Nuclear Medicine & \\
\hline Neurosurgery & \\
\hline Neurology & \\
\hline Pediatric Neurology & \\
\hline Obstetrics and Gynecology & \\
\hline Ophthalmology & \\
\hline Orthopedics and Traumatology & \multirow{2}{*}{$\begin{array}{l}\text { Derived from Obstetrics and Gynecology: } \\
\text { - Oncologic Gynecology } \\
\text { - Maternal Fetal Medicine }\end{array}$} \\
\hline Otolaryngology & \\
\hline Pediatrics & \multirow{7}{*}{ 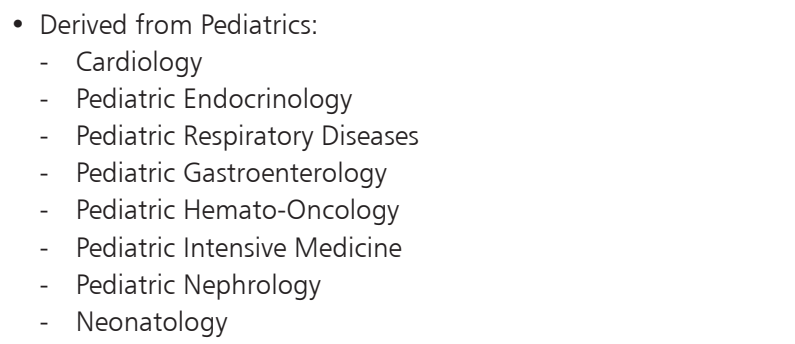 } \\
\hline Psychiatry & \\
\hline Child and Adolescents Psychiatry & \\
\hline Radiology & \\
\hline Oncologic Radiotherapy & \\
\hline Public Health & \\
\hline Urology & \\
\hline
\end{tabular}

found that choices varied depending on gender: men mostly prefer surgical specialties and women lead in specialties such as Obstetrics-Gynecology and Pediatrics ${ }^{7,9,10}$. By contrast, a study carried out in Pakistan during 2017 showed that women tended to choose surgery and Internal Medicine over the Gynecology and Pediatrics specialties, thus reflecting a change in the pattern shown before in various works and pointing out the need to widen the study of gender as a choice predictor factor ${ }^{11}$.
Research about differences in choice criteria found that, at the moment of choosing, the variety of medical problems and duration of the specialty, the type of work and experiences during the clinical internship were more relevant for women, while the possibility of doing research, pleasant academic experiences, having abilities related to the specialty, the possibility to obtain income more quickly, autonomy and the possibility of studying a sub-specialty are more important to $\mathrm{men}^{7,10}$. 


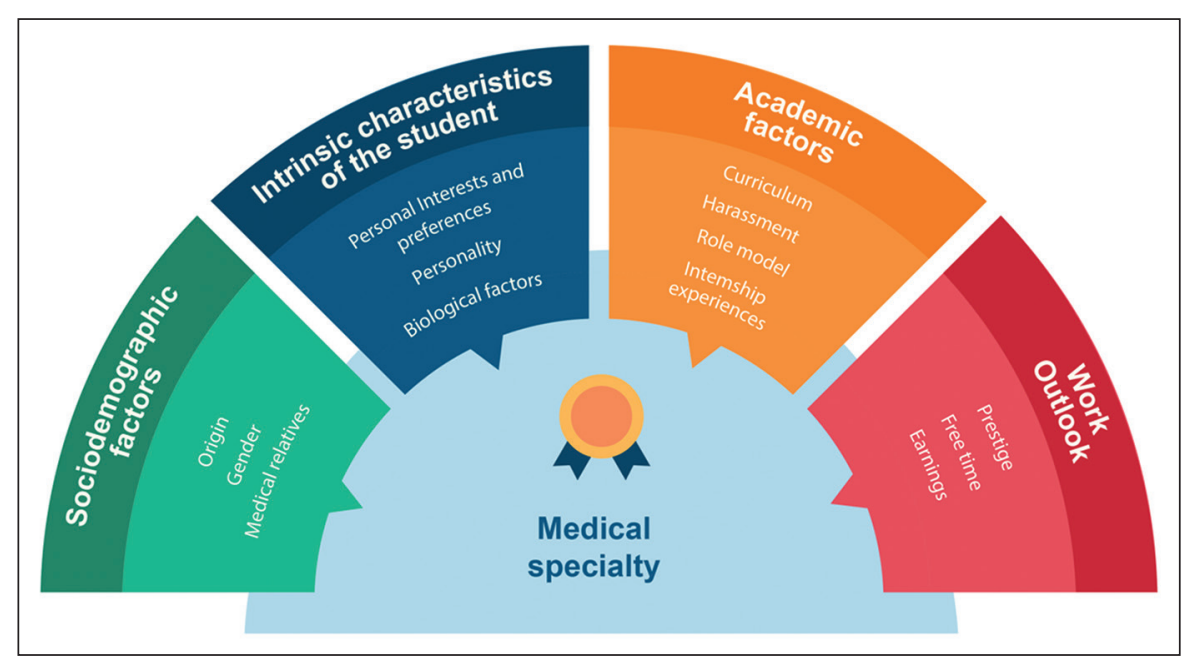

Figure 1. Classification of the factors associated to the choice of a medical specialty.
Research has described that women mostly choose specialties linked to managing chronic patients, palliative care, and a controlled lifestyle, with differences depending on the country of the and finding these factors less relevant in countries such as Sweden and the Netherlands ${ }^{3}$.

Another factor associated to the medical specialty choice is to have a medical relative or acquaintance engaged in a specific specialty. Brazilian researchers observed that the relatives' influence was significant only when the parents were physicians ${ }^{12}$, excepting the preference for Family Medicine ${ }^{8}$. On the other hand, a Japanese study revealed that those students who opted for General Medicine, and Emergency Medicine had physician parents in a low percentage, and those with a physician parent and plans to open their clinic tended to choose internal medicine as a specialty in greater proportion'.

\section{Intrinsic characteristics of the student}

A meta-analysis found that the factors that students consider when choosing a specialty are their academic interests and competencies, this being more relevant in developed countries than in the developing world ${ }^{6}$. This can be appreciated in that students that consider General Surgery, Family Medicine, and Obstetrics-Gynecology as eventual specialty, state that having the required abilities for the specialty was generally a relevant factor ${ }^{7}$.
On the other hand, the personality, understood as affective characteristics, experiential and motivational of a person, reflected in values, attitudes, and coping strategies ${ }^{13}$. has been studied assessing its influence as a medical specialty choice predictor $^{3}$. A Finnish study addressed the "Person-Job fit" theory, and postulated that personality traits would allow predicting how a person will adapt to a specific job or organization ${ }^{13}$.

Although the association with a certain type of personality has been described for each specialty, it cannot be said that these are determined a priori by a specific type, since physicians, like all people, can show complex personality traits pattern ${ }^{14}$.

Table 2 synthetizes the studies that address the relationship between personality and the chosen specialty.

In Peru, concrete thinking and stress straits predominate in medical students who prefer clinical specialties ${ }^{15}$. While in Mexico they were described as more patient, gentle, kind, with a general deeper emotional response. This study also expounded that a higher score in the modesty flexibility, perfectionism, emotivism, kindness, honesty and humility traits were predictors of this preference ${ }^{14}$.

Also, in Peru, traits of dominance and openness to change predominate in those who prefer surgical specialties ${ }^{15}$. In Mexico, they were described as less modest, more extrovert, more diligent, more organized, and in general less emotional, finding that higher scores in the field of extroversion and 
Table 2. Relationship between personality traits and chosen specialty, according to literature

\begin{tabular}{|c|c|c|}
\hline Specialty & Personality trait & País \\
\hline Internal Medicine & $\begin{array}{l}\text { Rigid, cold, sceptic, prefer to work with things rather than persons. } \\
\text { High conscientiousness given their high self-confidence. Diligent, painstaking }\end{array}$ & $\begin{array}{l}\text { Mexico (3) } \\
\text { Finland (13) }\end{array}$ \\
\hline Gynecology-Obstetrics & More extrovert, with more sensitive thought and judgment. & Mexico (3) \\
\hline Psychiatry & $\begin{array}{l}\text { Higher responsibility levels and slightly high of extraversion, higher levels of openness } \\
\text { to experience, neuroticism and agreeableness. Lower levels of conscientiousness. }\end{array}$ & Finland (13) \\
\hline Pediatrics & Extroverts sensorial, with rational thought and qualifier judgment. & $\begin{array}{l}\text { Mexico (3) } \\
\text { Finland (13) }\end{array}$ \\
\hline Surgery & $\begin{array}{l}\text { Higher capability to adapt to change, extroverts and open. Low agreeableness level } \\
\text { and neuroticism. Tending to be organized, careful and persistent. }\end{array}$ & $\begin{array}{l}\text { Mexico (3) } \\
\text { Finland (13) }\end{array}$ \\
\hline Orthopedics & More traits of perfectionism and stress. Perfectionism & Mexico (3) \\
\hline Otolaryngology & $\begin{array}{l}\text { Higher openness to experience } \\
\text { Less openness to experience }\end{array}$ & $\begin{array}{l}\text { Mexico (3) } \\
\text { Finland (13 }\end{array}$ \\
\hline Genetics & Higher openness to experience & Mexico (3) \\
\hline Ophthalmology & Less openness to experience & Finland (13) \\
\hline
\end{tabular}

organizational traits predicted this preference ${ }^{14}$. They also showed lower levels of kindness ${ }^{13}$ and higher extroversion levels, which would be evident from the first year of their formation ${ }^{3}$. However, in Saudi Arabia, this same type of student showed high scores of "neuroticism-anxiety", "searching for impulsive sensations", "aggression-hostility", and "sociability"16.

A study from Croatia showed that the students who reached higher scores in sympathy and openness (intellect/imagination) would lean towards psychiatry, and the more diligent students preferred anesthesiology, and emergency medicine ${ }^{17}$. In Peru, strong introversion was linked to specialties supporting diagnosis or administration ${ }^{15}$.

Some authors additionally suggest that there is a "biological predetermination" in those who seek a surgery career, this is supported by the findings of a study in medical students from the United States. The testosterone and cortisone levels were measured, as well as the ratio between the second and fourth finger (2D-4D) as an approximate measurement of the exposure to testosterone and estrogens in the uterus, and the data were associated to the preference for a surgery or non-surgery specialty The group preferring surgery had a 2D-4D ratio significantly lower, higher scores in competitiveness and lower ones in anxiety, as well as a significantly higher testosterone delta and a lower cortisol delta than the non-surgery preference group ${ }^{18}$.

\section{Academic factors}

Among academic factors, a Brazilian study pointed out two factors that favor the specialty choice: in the first place, the influence of a model teacher ${ }^{8}$. Yang states that the exposure to mentors in specific fields of medicine, such as internal medicine is strongly associated to the specialty chosen by the students ${ }^{6}$. Furthermore, even the stereotypes of specialties shown in television series or movies would have an influence at the time of deciding ${ }^{19}$.

The practical activities followed during internships are in second place ${ }^{8}$. A greater exposure of students to general practice, as well as a positive experience in a specialty, would influence following that course $\mathrm{e}^{7,20}$. This contrasts with Mexican findings, where exposing the students to academic experiences linked to primary care did not appear to modify the election rates ${ }^{7}$. On the other hand, the internships' sequences and the design of the study plan could influence the specialty choice ${ }^{3}$. Furthermore, early exposure to clinical practice would increase interest in some specialties, an improved competency in that field ${ }^{6}$. 
Medical students' harassment experiences during formation are another factor. Up to $91 \%$ of the students have suffered some kind of harassment and revealed that this situation had affected their social life and the image they had of the physicians and their mental state ${ }^{21}$, even to the point of having doubts about their profession ${ }^{22}$. However, no data about the repercussion on the choice of specialty were found ${ }^{21,22}$.

\section{Work prospects}

Yang revealed that income is an influential factor, especially in those countries where higher education has a heavy cost for students ${ }^{6,3}$. Furthermore, having to pay the loans for the financing of the career orients the students to specialties that they perceive as being better sources of income, preferring surgery specialties ${ }^{3,16}$ and lowering the predilection for specialties such as Family Medicine $^{6}$.

This agrees with a study carried out in Sweden, showing that medical specialties are perceived as having different status in the power field, Surgery being the predominant specialty ${ }^{23}$. This fact has been supported by other studies, where it has been shown that medical students who prefer Surgery consider that the prestige of the specialties is of major importance at the time of deciding ${ }^{7}$.

The "social dominance" theory may explain the choice of a specialty with higher status in a specific social system, because persons prefer hierarchy and therefore prestige. Students with higher "social dominance" chose specialties with greater technical orientation and prestige (such as Surgery, Internal Medicine and Anesthesiology), this increases over time, as social dominance would be lower at the start of the clinical years. This effect seems to become stronger as the exposure to sub-specialties with greater prestige and hierarchy increases ${ }^{3}$.

It has also been noted that students who focus themselves on primary care specialties are less influenced by the perception of the prestige that they shall acquire, than those who center themselves in more prestigious specialties of other fields ${ }^{12}$.

On the other hand, the type of patients is more important for those who prefer Internal Medicine, Pediatrics and Obstetrics-Gynecology, over Surgery and Family Medicine ${ }^{7}$, For Internal
Medicine, the motivation would be the possibilities to take part in terminal care, access to complex pathologies and clinical diagnosis reasoning. For Pediatrics, communication with the patients and social of the specialty seem important ${ }^{7}$; for Surgery and emergency medicine the treatment of acute pathologies is of interest ${ }^{9}$.

During the last few years, a change has taken place among medical students concerning the choice of specialties that offer greater control over lifestyle and working patterns ${ }^{3}$ although the availability of free time is limited in almost all specialties. It has been perceived that this factor is more significant for those who prefer Family Medicine and less relevant for those who want to follow Surgery ${ }^{7}$. Furthermore, the less flexible lifestyle of Surgery is an usual reason for the students to view this specialty as less appealing.

On the other hand, students who want to develop new abilities, master advanced procedures and accede to innovative medical fields mostly prefer Surgery ${ }^{9}$ in contrast with those who prefer Obstetrics-Gynecology and Internal Medicine and consider the possibility of carrying out research within the specialty of lesser importance ${ }^{7}$. Regarding family relationships, those who prefer Family Medicine, their family's support and the wish to form a family are more relevant ${ }^{7}$.

\section{Discussion}

The choice of specialty should result from the balance between the interest of the professional and the needs of the citizens, as the distribution and imbalance of the specialties has a direct impact on health systems operations ${ }^{8}$.

The primary care specialties are seen as less prestigious, limiting their election. However, the evidence shows that the increase of physicians in this field, especially family doctors, improves the population's health, promotes equality in care, and reduces the health system's expenses, in contrast to the increase of specialists ${ }^{8}$. To eliminate such preconceptions would help the students pay attention to lesser demanded fields and increase interest in other specialties ${ }^{6}$.

Similarly, changes in health management could regulate the work overload in some specialties that are considered incompatible with personal life. These changes could open the door to people 
who exclude themselves from these specialties and promote more healthy environments for those who work precisely in health care.

In this context, it is possible to propose a series of interventions such as personalized extracurricular training, as well as surgical or clinical internships, according to the students' preferences, added to the exposure to positive models among the schools of medicine teaching staffs, to favor decision-making in the future health professionals ${ }^{14,20}$. If countries identify the factors that influence the students' specialty choosing, they can better understand the present shortage or surplus in specific fields. It also contributes to the construction of policies and decision-making to improve the students' future formation and recruitment (6), and helps them to generate appropriate incentives for future generations to choose specialties their communities need.

This added to changes in the process for entering into specialties to prevent situations in countries where choosing a specialty can be hindered for variables inherent to the selection process, such as the limited number of openings ${ }^{7}$.

In Chile, the choice of medical specialty has little updated evidence. In 2005 a study evaluated its relationship with personality with results similar to other Latin American studies ${ }^{24}$. However, this is not the only factor that influences this choice.

Long lists of patients waiting for specialist care in the public sector are associated with dissatisfaction among the population. Chilean had a deficit of 3,795 specialists affecting 1,500,000 users in $2014^{2,4}$. Although the Government developed national strategies to reduce this deficit ${ }^{2}$, the extent of the problem makes it necessary to continue advancing in policies to increase the resources allocated to training specialists ${ }^{4}$. This, together with funding difficulties and legal problems related to the practice of the profession have led to a growing interest in derived specialties to the detriment of basic ones ${ }^{24}$.

In Chile, $92 \%$ of fellowship-trained physicians are in the program they wished to follow, unlike general practitioners, where only half of them chose to do $\mathrm{so}^{24}$. Furthermore, only approximately $50 \%$ of physicians pursue some specialty in Chile ${ }^{3}$. The other 50\% would represent an opportunity to diminish the deficit if their reasons for declined a specialties were known.

In Chile, there is a discordance between the high demand for fellowships and specialist care and the supply of admission to training programs for general practitioners. So, any public policy to strengthen socially relevant medical specialization should consider the aspects affecting the specialty choice, such as those mentioned in this article.

\section{References}

1. Nolla, N. Los planes de estudio y programas de las especialidades médicas. Educ Méd Sup. 2001; 15 (2): 147-58.

2. Clouet-Huerta D, González B, Correa K. Especialización médica en Chile: tipos, mecanismos y requisitos de postulación. Una actualización de los procesos para los médicos generales. Rev Med Chile 2017; 145 (11): 1454-62.

3. Gutiérrez-Cirlos C, Naveja J, Sánchez-Mendiola M. Factores relacionados con la elección de una especialidad en medicina. Inv Ed Med. 2017; 6 (23): 206-14.

4. Ruiz J, Enríquez M, Gómez E, León S. Relación entre rasgos y tipos de personalidad con la especialidad médica elegida por un grupo de médicos residentes. Inv Ed Med. 2016; 5 (20): 238-43.

5. Paulsen C. Programas De Especialidades Médicas En Chile. EUNAmed. 2020. Disponible en: https://eunamed.com/blog/especialidades-medicas-en-chile/

6. Yang Y. Factors influencing subspecialty choice among medical students: A systematic review and meta-analysis. BMJ 2019; 9 (3): 1-12.

7. Gutiérrez-Cirlos C, Naveja J, García-Minjares M, Martínez-González A, Sánchez-Mendiola M. Specialty choice determinants among Mexican medical students: a cross-sectional study. BMC Med Educ. 2019; 19 (1): 1-8.

8. Rodrigues L, Duque T, Silva R. Fatores Associados à Escolha da Especialidade de Medicina de Família e Comunidade. Rev bras educ med. 2020; 44 (3): e078.

9. Ie K, Murata A, Tahara M, Komiyama M, Ichikawa S, Takemura Y, Onishi H. Relationship between medical students' career priority and specialty choice: A nationwide multicenter survey. J Gen Fam Med 2020; 21 (6): 219-25.

10. Asaad M, Zayegh O, Badawi J, Hmidi Z, Alhamid A, Tarzi M, et al. Gender differences in specialty preference among medical Students at Aleppo University: a cross-sectional study. BMC Med Educ. 2020; 20: 184.

11. Shabnam H, Syed A, Hamza J, Romasa Z. Specialty preference with respect to gender among medical students of Pakistan. J Pak Med Assoc. 2019; 69 (8): 1190-3. 
12. Martins J, Rodríguez F, Coelho I, Silva E. Fatores que Influenciam a Escolha da Especialização Médica pelos Estudantes de Medicina em uma Instituição de Ensino de Curitiba (PR). Rev Bras Educ Med. 2019; 43 (2): 1528.

13. Mullola S. Personality traits and career choices among physicians in Finland: Employment sector, clinical patient contact, specialty and change of specialty. BMC Med Educ. 2018; 18 (1): 52.

14. Barbosa-Camacho F, Miranda-Ackerman R, Vázquez-Reyna I, Jiménez-Ley V, Barrera-López F, Contreras-Cordero V, et al. Association between HEXACO personality traits and medical specialty preferences in Mexican medical students: a cross-sectional survey. BMC Psychol. 2020; 8 (1): 1-9.

15. Alejo A, Castro J. Rasgos de Personalidad y Atracción por una Especialidad Médica, en Internos de Medicina. Revista Médica Corriónica 2017; 4 (1).

16. Jhonnel J, Changllio-Calle G, Cahuana-Salazar M. Asociación entre las perspectivas salariales y la elección de especialidades quirúrgicas en estudiantes de medicina de una universidad pública de Perú. FEM 2018; 21 (5).

17. Milić J, Škrlec I, Milić I, Jakab J, Plužarić V, Heffer M. Importance of the big-five in the future medical specialty preference. BMC Med Educ. 2020; 20: 234.

18. Crewther B, Cook C. Medical students preferring a surgical or non-surgical elective differ in their emotional and hormonal responses to a psychological stressor. Am
J Surg. 2020; 219 (4): 604-7.

19. Sánchez M. ¿Qué vas a hacer el resto de tu vida?: la elección de una especialidad médica. Inv Ev Med. 2017; 6 (23): 145-14.

20. Arshad S. What factors influence medical students to enter a career in general practice? A scoping review. Ir J Med Sci. 2020; 1-9.

21. Paredes O. "Bullying" en las facultades de medicina colombianas, mito o realidad. Revista Med. 2010; 18 (2): 161-72.

22. Colenbrander L. 'If you can't make it, you're not tough enough to do medicine': a qualitative study of Sydney-based medical students' experiences of bullying and harassment in clinical settings. BMC Med Educ. 2020 [Consultado el 5 de noviembre de 2020]; 20 (86): 1-12.

23. Olsson C, Kalén S, Ponzer S. Sociological analysis of the medical field: using Bourdieu to understand the processes preceding medical doctors' specialty choice and the influence of perceived status and other forms of symbolic capital on their choices. Adv Health Sci Educ 2019; 24, 443-457.

24. Bitrán M, Zúñiga D, Lafuente M, Viviani P, Mena B. Influencia de la personalidad y el estilo de aprendizaje en la elección de especialidad médica. Rev Med Chile 2005; 133 (10): 1191-9.

25. Torres-Quevedo R. Déficit de médicos especialistas en las regiones y en el sistema público. Rev Chil Cir. 2016; 68 (4): $279-80$. 